\title{
KINERJA TIM AKREDITASI PADA PROSES AKREDITASI PROGRAM STUDI (Studi Kasus: Tim Akreditasi Program Studi di STKIP YPM Bangko)
}

\author{
Mardalena $^{1}$
}

\begin{abstract}
Performance of human resource becomes one of the significant role in the running of the organization. This research, the human resource are the personnel team acreditation of English education study program in STKIP YPM Bangko. Personel team is the central part in deciding the readiness of studi program in preparing the acreditation. Acreditaiton team consist group of lecturers in ensuring the process of acreditation Tim akreditasi adalah sekumpulan orang yang diharapkan untuk menjamin kesiapan prodi pada proses akreditasi dalamand later on in getting excellent result of acreditation by National Institution of Acreditation. in short, performance of acreditation team will determine the result of the acreditation.
\end{abstract}

\section{Key Words: Work Performance, Human Resource, Accreditation}

\section{PENDAHULUAN}

Berdasarkan

Pemerintah Republik

Peraturan nomor 60 tahun 1999, dinyatakan bahwa tujuan pendidikan tinggi: a) menyiapkan peserta didik menjadi anggota masyarakat yang memiliki kemampuan akademik dan/atau profesional yang dapat menerapakan, mengembangkan dan/atau memperkaya khasanah ilmu pengetahuan teknologi dan/atau kesenian, b) mengembangkan dan menyebarluaskan ilmu pengetahuan, teknologi dan atau kesenian serta mengupayakan penggunaannya untuk meningkatkan taraf kehidupan masyarakat dan memperkaya kebudayaan nasional.

Guna peNcapaian tujuan tersebut, kinerja seluruh unit yang terdapat dalam lembaga pendidikan tinggi akan dikerahkan secara optimal. Sehingga kinerja sumber daya manusia (SDM) menjadi komponen yang sangat penting. Akreditasi unggul merupakan pengakuan atas kinerja seluruh unit pada lembaga pendidikan. Dalam penelitian ini, peneliti akan mengkaji

\footnotetext{
${ }^{1}$ STKIP YTM Bangko
}

kinerja SDM khususnya pada tim persiapan akreditasi program studi. Dibeberapa tim akreditasi dijumpai beragam masalah, misalnya; rendahnya motivasi personel dalam menyiapkan akreditasi. Tingginya angka ketidakhadiran pada saat tim mengadakan pertemuan. Terlambatnya pengumpulan data maupun tertundanya beberapa target atau bahkan tim tidak mampu menyesuaikan pekerjaan sesuai jadwal yang telah ditentukan. Tidak lengkapnya data yang dikumpulkan. Untuk itu rumusan tujuan dalam penelitian ini adalah untuk mengetahui kinerja personel tim akreidtasi prodi PBI. Tujuan penelitian akan dicapai dengan diawali menginventarisir secara lebih rinci permasalahan-permasalahan yang ditemukan khususnya terkait dengan indikator kinerja pada tim akreditasi program studi. Guna kemudian akan ditemukan solusi paling ideal terhadap masalah tersebut. Hasil penelitian ini juga juga diharapkan memberikan pengalaman dan informasi khususnya bagi tim akreditasi dalam pengefektifan kerja tim akreditasi menyelesaikan proses akreditasi 


\begin{tabular}{rlllr}
\hline tepat waktu dan meraih & peringkat akreditasi unggul. \\
nilai/peringkat akreditasi unggul. & Sementara itu, Sevilla (1998) \\
Dalam Kamus Besar Bahasa & berpendapat bahwa kinerja adalah \\
Indonesia (KBBI) kinerja adalah & apa yang seseorang lakukan.
\end{tabular}

Sesuatu yang dicapai. Hellriegel and Slocum (1994) menjelaskan pula bahwa istilah kinerja (performance) dapat digunakan dalam beragam makna, misalnya; perbuatan, daya guna, prestasi, hasil, pelaksanaan kewajiban/tugas. Kinerja merupakan tingkat keberhasilan kerja seseorang. Dalam penelitian ini, keberhasilan kerja tim akreditasi program studi dalam melaksanakan tugas dan tanggungjawab guna meraih
Sementara itu, Gibson, et al, (1985) mengungkapkan bahwa kinerja juga erat kaitannya dengan perilaku individual dan dipengaruhi oleh berbagai faktor seperti faktor individu terdiri dari kemampuan dan keahlian, pengalaman, dan keluarga. Faktor psikologi terdiri dari motivasi, sikap/perilaku, kepribadian, dan persepsi. Faktor organisasi terdiri dari kepemimpinan dan struktur organisasi.

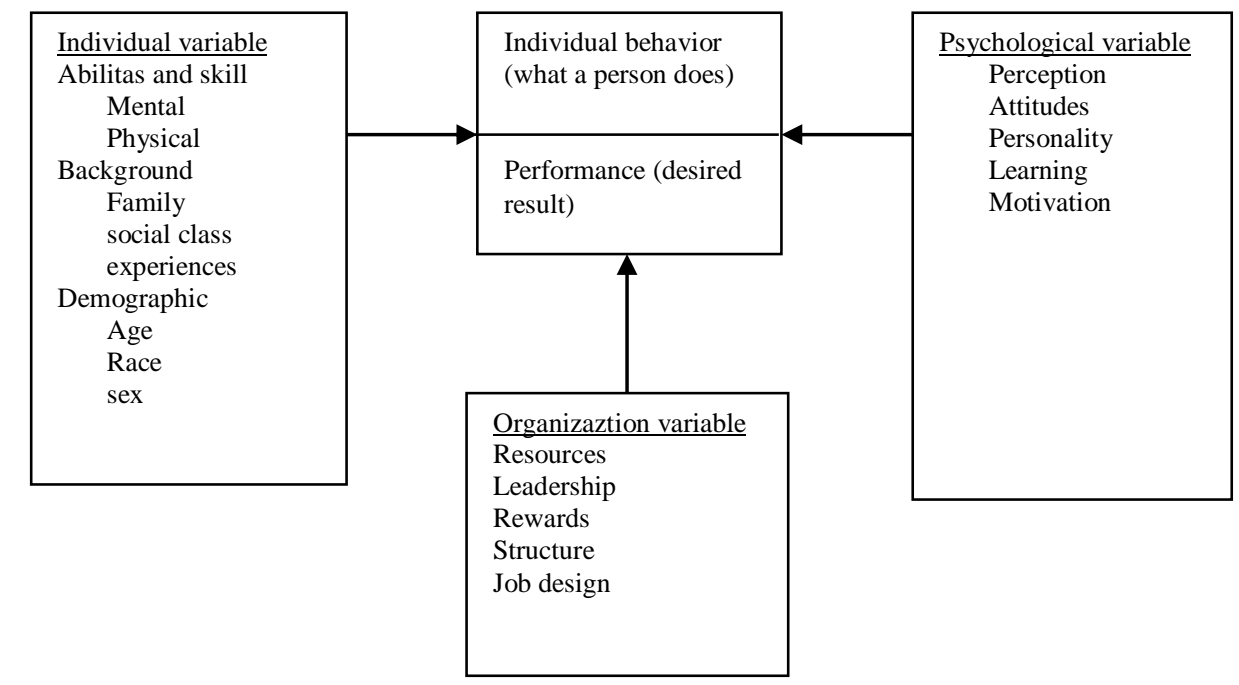

Sumber: James L Gibson, John M. Ivancevich, dan James H. Donnely, Jr. Organization (Texas: Business Publication, Inc., 1985), p. 57.

Berdasarkan gambar di atas diketahui bahwa kinerja sangat erat kaitannya dengan tingkah laku (behavior). Hal ini dikarenakan bahwa tingkah laku adalah segala sesuatu yang dilakukan leh seseorang. Selanjutnya diketahui juga bahwa baik tingkah laku dan kinerja dapat dipengaruhi oleh faktor individu, organisasi, dan psikologis.

Selanjutnya Steer, et al (1960) mengungkapkan pula bahwa kinerja (performance) merupakan hasil dari pelaku seseorang. Masingmasing individu akan berperilaku dan menghasilkan kinerja yang berbeda pula. Hal ini dikarenakan faktor individu; kemampuan dan keahlian, pengalaman dan bahkan gender. Setiap individu dilahirkan dan dibesarkan dengan lingkungan dan cara yang unik. Sevilla, et al (1998) mengatakan bahwa pengalaman yang didapat oleh masing-masing individu akan sangat beragam yang turut menentukan beragamnya motivasi dan cara seseorang dalam melakukan sesuatu dalam pemenuhan kebutuhannya.

Selanjutnya, Mangkunegara (2002) menyatakan bahwa kinerja dapat dolihat dari: 1) memiliki 
tanggung jawab pribadi yang tinggi, 2) berani mengambil dan menanggung resiko yang dihadapi, 3) memiliki tujuan yang realistis, 4) memiliki rencana kerja yang menyeluruh dan berjuang untuk merealisasi tujuannya, 5) memanfaatkan umpan balik (feed back) yang konkrit dalam seluruh kegiatan kerja yang dilakukannya, dan 5) mencari kesempatan untuk merealisasikan rencana yang telah diprogramkan.

Penilaian

kinerja dilaksanakan guna memastikan dan menilai proses kerja pada tiap individu yang dapat dijadikan dasar pengambilan keputusan peningkatan karir. Penilaian kinerja juga dilakukan guna penyusunan rencana ataupun mengevaluasi dan mengetahui keunggulan dan kelemahan terhadap tugas yang telah diberikan.

Penilaian kinerja dapat dilihat dari beragam sektor. Robbins (2006) mengatakan setidaknya terdapat lima indikator, sebagai berikut:

1. Kualitas

Kualitas kinerja dapat diukur dari persepsi teman sejawat terhadap kualitas pekerjaan yang dihailkan serta kesempurnaan tugas terhadap keterampilan dan kemampuan karyawan.

2. Kuantitas

Pengukuran kuantitas dilihat dari sudut pandang jumlah kerja yang dihasilkan

3. Ketepatan waktu

Penilaian kinerja berdasarkan tingkat aktivitas yang mampu diselesaikan pada awal waktu yang telah dirancang. Namun jika dilihat dari sudut koordinasi, dapat dinilai dari hasil yang memaksimalkan waktu yang tersedia untuk aktivitas lainnya.

4. Efektivitas
Penilaian ini ditinjau dari penggunaan sumber daya (tenaga, uang, teknologi, bahan baku) secara maksimal dengan maksud menaikkan hasil dari setiap unit dalam penggunaan sumber daya.

5. Kemandirian

Penilaian dari tingkat individu yang nantinya akan dapat menjalankan tanggungjawab dan komitmen kerja.

Sementara itu, Mangkunegara (2002) mengemukakan bahwa indikator kinerja, dapat dilhat dari :

1. Kualitas

Kualitas kerja adalah seberapa baik seorang karyawan mengerjakan apa yang seharusnya dikerjakan.

2. Kuantitas

Kuantitas kerja adalah seberapa lama seorang pegawai bekerja dalam satu harinya. Kuantitas kerja ini dapat dilihat dari kecepatan kerja setiap pegawai itu masing-masing.

3. Pelaksanaan tugas

Pelaksanaan

Tugas adalah seberapa jauh karyawan mampu melakukan pekerjaannya dengan akurat atau tidak ada kesalahan.

4. Tanggung Jawab

Tanggung jawab terhadap pekerjaan adalah kesadaran akan kewajiban karyawan untuk melaksanakan pekerjaan yang diberikan perusahaan.

Dari beragam pendapat para ahli di atas, maka sintesis dari kinerja adalah sebuah hasil yang dapat dilihat dari beberapa indikator yakni; efektiviitas dan efisiensi, tangung jawab, disiplin dan inisiatif.

\section{METODOLOGI PENELITIAN}

Sesuai dengan rumusan dan tujuan penelitian, maka penelitian ini dirancang dengan menggunakan mixed method. Hal ini dikarenakan peneliti menggabungkan data 
kuantitaf dan data kualitatif dalam pengumpulan dan analisis data. Populasi penelitian ini adalah seluruh personel yang tertuang dalam Surat Keputusan tim akreditasi prodi pendidikan Bahasa Inggris STKIP YPM Bangko, kecuali para unsur pimpinan (pelindung dan penanggung jawab).

Penelitian ini dilakukan Sekolah Tinggi Keguruan dan Ilmu Pendidikan (STKIP) Yayasan pendidikan Merangin (YPM) Bangko. Objek penelitian adalah Program Studi (prodi) Pendidikan Bahasa Inggris (PBI) STKIP YPM Bangko. Unit analisis dalam penelitian ini adalah tim akreditasi prodi PBI. Populasi merupakan seluruh dosen dan staf prodi PBI yang terdiri atas 14 dosen dan 1 staf. Namun yang menjadi sampel penelitian berjumlah 10 orang. Hal ini dikarenakan 2 orang dosen tidak dapat dilibatkan dalam tim dikarenakan sedang studi lanjut dan 1 orang dosen menjabat sebagai pimpinan STKIP, dan 1 orang dosen sedang proses pindah homebase. Dalam hal ini, responden merupakan unsur pimpinan STKIP YPM Bangko (Ketua YPM, Wakil Ketua YPM, Sekretaris YPM, Bendahara YPM, Ketua STKIP, Wakil Ketua I STKIP, Wakil Ketua II STKIP, Wakil Ketua III STKIP, Kepala Penjamin Mutu) yang keseluruhan berjumlah 9 orang. Teknik pengumpulan data dilakukan dengan pengembangangan instrumen berupa angket dan list of interview. Angket dan list of interview dibangun berdasarkan teori-teori tentang indikator kinerja. Instrumen angket tersebut divalidasi oleh pakar yang memiliki latar belakang ilmu manajemen pendidikan. Angket terdiri atas 33 butir; dengan 4 indikator; efektivitas dan efesiensi (10 butir), tanggungjawab (8 butir), disiplin (6 butir) dan inisiatif (9 butir). Sementara itu, list of interview terdiri atas 12 pertanyaan yang dikembangkan dari 4 indikator kinerja. Setelah data berupa angket dan interview diperoleh maka kemudian, data tersebut akan dianalisis dengan menggunakan statistik deskriptif.

\section{HASIL PEMBAHASAN}

STKIP YPM Bangko terus menyiapkan diri dalam merealisasikan visi misi lembaga yakni menjadi lembaga pendidikan tinggi yang berkualitas dan kompetitif berlandaskan ketaqwaan. Pendidikan tinggi yang berkualitas dapat ditandai dengan beragam indikator. Namun indikator utama pendidikan tinggi yang berkualitas adalh pengakuan Badan Akreditasi Nasional dengan peringkat unggul.

Untuk itu, peneliti telah melaksanakan penelitian guna mengukur kinerja khususnya pada tim akreditasi prodi Pendidikan Bahasa Inggris. Kinerja tim tersebut sangat penting dalam menunjang kelancaran proses akreditasi. Dari instrumen angket (data kuantitatif) yang diberikan kepada seluruh personel tim akreditasi prodi dapat dilihat sebagai berikut:

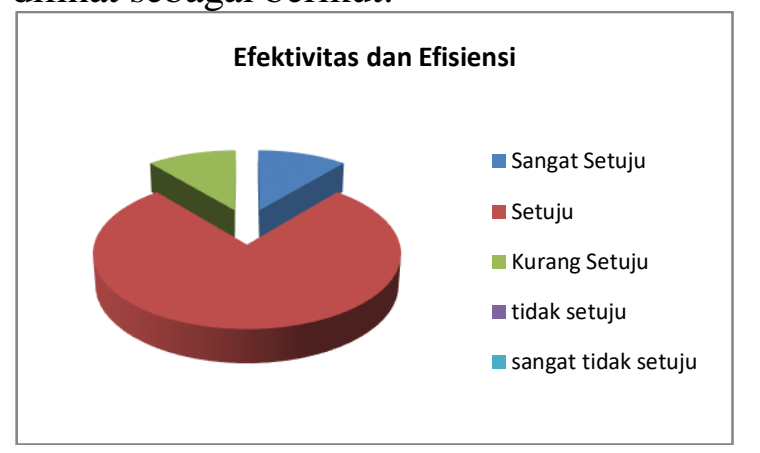
Chart 1. Kinerja Tim pada Indikator
Efektivitas dan Efisiensi

Dari chart di atas diketahui bahwa kinerja personel tim akreditasi pada indikator efektivitas dan efisiensi; 7 orang (78\%) responden menjawab setuju, masing-masing 1 
orang (11\%) responden menjawab setuju dan kurang setuju.

Berikut ini adalah kinerja tim dillihat dari indikator tanggung jawab. Data tersebut dapat dilihat pada chart di bawah ini:

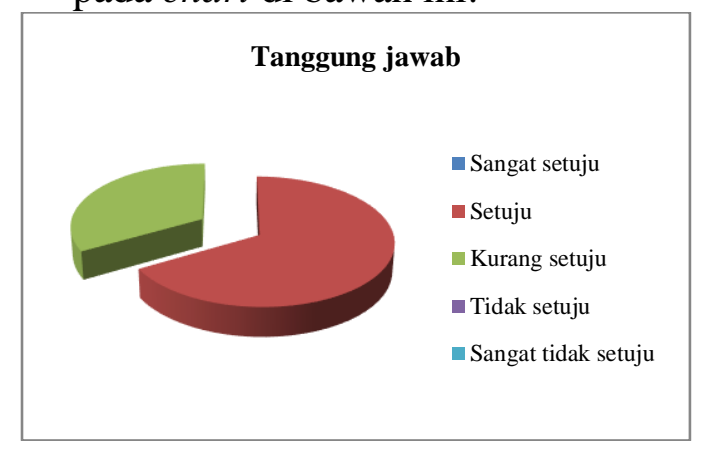

Chart 2. Kinerja Tim pada Indikator Tanggung Jawab

Dari chart di atas diketahui bahwa kinerja personel tim akreditasi pada indikator tanggung jawab; 6 orang (67\%) responden menjawab setuju, dan 3 orang (33) responden menjawab kurang setuju.

Berikut ini akan dipaparkan pula kinerja tim dillihat dari indikator disiplin. Data tersebut dapat dilihat pada chart di bawah ini:

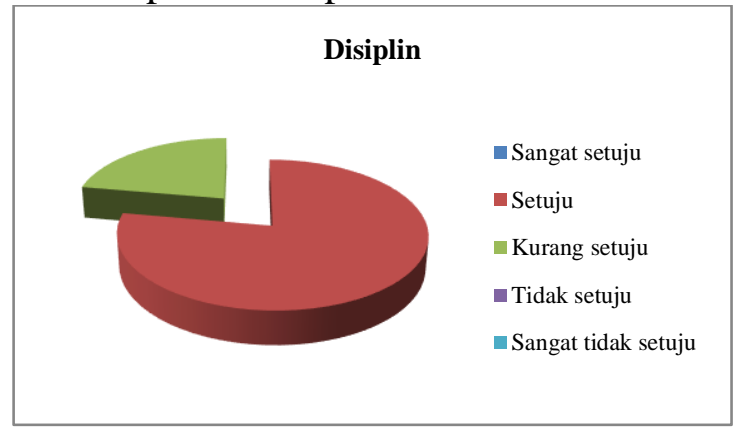

Chart 3. Kinerja Tim pada Indikator Disiplin

Dari chart di atas diketahui bahwa kinerja personel tim akreditasi pada indikator disiplin; 7 orang (78\%) responden menjawab setuju, dan 2 (22) orang responden menjawab kurang setuju.

Berikut ini adalah data kinerja tim dillihat dari indikator inisiatif. Data tersebut dapat dilihat pada chart di bawah ini:

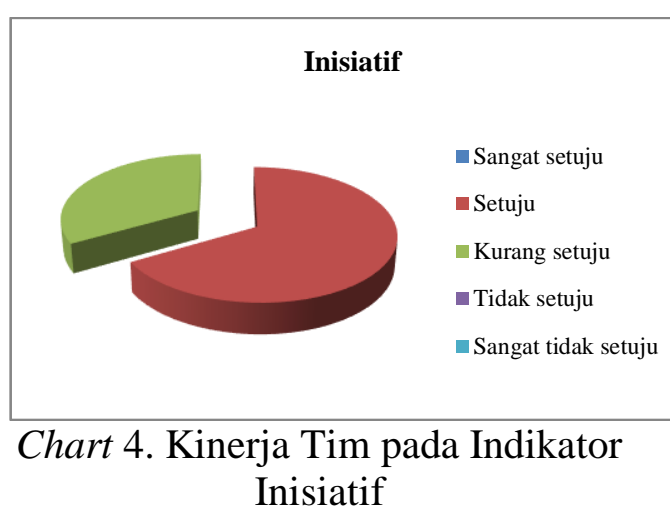

Dari chart di atas diketahui bahwa kinerja personel tim akreditasi pada indikator disiplin; 6 orang (67\%) responden menjawab setuju, dan 3 orang (33\%) responden menjawab kurang setuju.

Sementara itu dari instrumen list of interview (data kualitatif) dari para informan yakni para unsur pimpinan yang ada di lingkungan YPM dan STKIP Bangko diketahui bahwa sebagian besar personel tim tidak mampu bekerja dengan efektif dan efisien. Hal ini terbukti dengan banyaknya personel tim mengeluh dalam bekerja dikarenakan tidak jeli melihat dan menggunanakan sumber daya yang ada. Sebagian personel tim tidak menunjukkan rasa tanggungjawab yang penuh. Hal ini ditandai dengan ketidaktelitian dalam mengerjakan tugas hingga hasilnya terkesan asal-asalan. Sebgaian personel tim juga terlihat masih rendah dalam disiplin. Hal ini ditandai dengan mundurnya masa pengisian borang yang kemudian juga berimbas pada keterlambatan pengiriman borang tepat pada $\mathrm{H}-1$ hari terakhir pengusulan borang dengan manual ke BAN-PT. Inisiatif personel tim diyakini masih sangat rendah. Hal ini ditandai dengan tim personel kurang mampu bekerja mandiri secara maksimal. Hasil kerja mandiri terkesan tidak teliti namun menghabiskan waktu yang sangat banyak. 
Dari 2 jenis data tersebut di atas, diketahui bahwa sebagian besar indikator yang telah dikemukan oleh beberapa ahli di atas, belum dapat ditemukan pada personel tim akreditasi prodi Pendidikan Bahasa Inggris STKIP YPM Bangko. Mangkunegara (2002) mengatakan bahwa kinerja dapat dilihat dari tanggung jawab. Di lapangan diketahui bahwa personel tim lebih sering diingatkan mengenai bentuk tugas dan tagihan jadwal yang diberikan.

Sementara itu, Robbins (2006) mengatakan bahwa kinerja dapat dilihat dari ketepatan waktu dan efektivitas. Data di lapangan mengemukakan bahwa jadwal pengisian dan pengiriman borang tertundan hingga 1 bulan. Personel tim juga dinilai tidak jeli melihat dan mengelola sumber daya secara optimal. Sehingga waktu berjalan cepat tanpa mampu menyelesaikan tugas di awal waktu.

\section{SIMPULAN}

Dari hasil analisis data di atas, maka dapat disimpulkan bahwa kinerja tim prodi PBI dinyatakan masih belum maksimal. Hal ini dibuktikan dengan terdapatnya personel tim yang masih tidak memiliki inisiatif, yang masih rendah tingkat kehadiran yang bahkan secara umum tim tidak dapat menyelesaikan tugas tepat waktu.

\section{Saran}

Sehubungan dengan hasil analisis terkait dengan kinerja tim akreditasi prodi PBI maka untuk pelaksanaan akreditasi berikutnya pada prodi-prodi yang lain malka disaran, sebagai berikut:1) ketua prodi harus mampu menjadi top role model pada seluruh indikator. Rekanrekan tim dapat mencontoh kinerja kaprodi sehingga berdampak positif bagi kelancaran proses penyelesaian akreditasi prodi, 2) personel harus memiliki kesadaran akan pentingnya akreditasi sehingga dalam pelaksanaanya tim mampu bekerja secara sadar akan tanggungjawab yang diemban, 3) unsur pimpinan harus selalu mengawasi kerja dan memfasilitasi kebutuhan tim, dan 4) pada akhir kerja tim, unsur pimpinan harus melakukan rapat evaluasi terhadap seluruh kinerja tim dengan memberikan apresiasi ataupun feedback.

\section{DAFTAR PUSTAKA}

Concuslo C. Sevilla, et al. 1988. General Psychologi: with Values Development Lesson. Manilla. Rex Book Store.

Don Hellriegel and Jhon W. Slocum, Jr. 1994. Management. Philipines. Addison Wesley Publishing Company, Inc.

James L. Gibson, et al. 1985. Organizations. Texas. Business Publication, Inc.

Mangkunegara, Anwar Prabu. 2002. Manajemen Sumber Daya Manusia. Remaja Rosdakarya. Bandung.

Robbins, Stephen P., 2006. Perilaku Organisasi. PT Indeks. Kelompok Gramedia. Jakarta. 